\title{
Kinerja Keuangan Badan Layanan Umum Rumah Sakit Se-Jabotabek
}

Sonny Sulaksono ${ }^{1}$, Darmansyah ${ }^{3}$

${ }^{1.2}$ Universitas Pancasila, Jl. Srengseng Sawah, Jagakarsa, Jakarta Selatan, 12640

INFO ARTIKEL

JEL Classsification:

H83

118

L25

Keywords:

cash ratio, receivable

turn over, firm size,

gross profit margin

\section{$A B S T R A C T$}

This study aims to identify and analyze the significant effect of cash ratio, receivable turn over, firm size on the financial performance proxyed by gross profit margin at General Hospital Service Agency located in Jakarta, Bogor, Tangerang and Bekasi. This research method using quantitative analysis method with secondary data retrieval, obtained from financial report data of hospital of Public Service Agency in Jabotabek area year 2013-2015 which measured by using ratio scale. The results of this study show that cash ratio partially does not affect significantly to gross profit margin, and the frequency of cash ratio movement that occurs partially has no impact on gross profit margin. Receivable turn-over is partially significant to gross profit margin, and the frequency of partially receivable turnover movements will have an impact on gross profit margin. Firm Size partially significant effect on gross profit margin, and firm size changes that occur partially impact on gross profit margin generated.

\section{A B S T R A K}

Penelitian ini bertujuan untuk mengidentifikasi dan menganalisis pengaruh signifikan cash ratio, receivable turn over, firm size terhadap kinerja keuangan yang diproksikan oleh gross profit margin pada Rumah Sakit Badan Layanan Umum yang berlokasi di wilayah Jakarta, Bogor, Tangerang dan Bekasi. Metode penelitian ini menggunakan metode analisis kuantitatif dengan pengambilan data sekunder, diperoleh dari data laporan keuangan rumah sakit Badan Layanan Umum di wilayah Jabotabek tahun 2013-2015 yang diukur dengan menggunakan skala rasio. Hasil penelitian ini menunjukkan cash ratio secara parsial tidak berpengaruh secara signifikan terhadap gross profit margin, dan frekuensi atas pergerakan cash ratio yang terjadi secara parsial tidak berdampak apapun terhadap gross profit margin. Receivable turn-over secara parsial berpengaruh secara signifkan terhadap gross profit margin, dan frekuensi pergerakan Receivable turn-over yang terjadi secara parsial akan berdampak pada gross profit margin. Firm Size secara parsial berpengaruh secara signifikan terhadap gross profit margin, dan perubahan firm size yang terjadi secara parsial berdampak terhadap gross profit margin yang dihasilkan.

*Email Korespondensi: ${ }^{1}$ sulaksonosonny@gmail.com,2darmansyah155@yahoo.com 


\section{Pendahuluan}

Saat ini, sumber daya yang dimiliki pemerintah terbatas, sedangkan kebutuhannya sangat tinggi. Diharapkan penggunaan dana pemerintah menjadi lebih fokus pada output yang memiliki nilai tinggi. Pola pengelolaan keuangan yang fleksibel, melalui praktek-praktek bisnis yang sehat dalam rangka memberikan pelayanan maksimal kepada masyarakat mengacu pada produktivitas, efisisensi, dan efektifitas melalui Badan Layanan Umum.

Peningkatan kinerja pelayanan publik yang berbasis pada hasil, akuntabiltas, tranparan dan profesionalitas, badan layanan umum khussnya rumah sakit tata kelola, rencana strategis bisnis, standar layanan minimal, laporan keuangan dan laporan audit/atau bersedia diaudit (Litaswari, 2016). Pemenuhan kebutuhan publik bidang kesehatan dituntut untuk dapat memberikan pelayanan prima. Dalam proses pemberian pelayanan prima tersebut tentu memerlukan sejumlah dana yang belum tentu selalu dapat tercukupi. Untuk mengatasi berbagai kendala yang terjadi.
Rumah sakit sebagai suatu organisasi yang komplek, padat modal dan padat teknologi, memerlukan biaya yang tinggi untuk memenuhi tuntutan peningkatan mutu pelayanan kesehatan, sehingga rumah sakit harus tetap konsisten untuk menjalankan misinya sebagai institusi pelayanan sosial, dengan mengutamakan pelayanan kepada masyarakat dengan selalu memperhatikan etika pelayanan (Candri, 2007). Rumah sakit dituntut untuk dapat melayani masyarakat, dapat berkembang dan mandiri serta harus mampu bersaing dan memberikan pelayanan yang bermutu dan terjangkau bagi masyarakat. Pengelolaan keuangan BLU rumah sakit diharapkan dapat meningkatkan profesionalisme, mendorong entrepreneurship, transparansi dan akuntabilitas dalam rangka pelayanan publik. Kinerja keuangan BLU rumah sakit belum memuaskan dan belum dikelolah dengan baik. (Sri Mulyani, 2007 dalam Meidyawati, 2011).

Kinerja keuangan pada badan layanan umum rumah sakit cenderung fluktuatif selama periode 2013 sampai 2015, seperti tabel 1 dibawah ini.

Tabel 1. Cash ratio, Receivable turn over, Firm Size dan Gross profit margin Rata-Rata Per Tahun Pada Rumah Sakit BLU di Jabotabek periode 2013 - 2015

\begin{tabular}{lccc}
\hline \multicolumn{1}{c}{ Uraian } & $\mathbf{2 0 1 3}$ & $\mathbf{2 0 1 4}$ & $\mathbf{2 0 1 5}$ \\
\hline Gross profit margin & $10,59 \%$ & $7,25 \%$ & $9,51 \%$ \\
Cash Ratio & 12,03 & 46,57 & 19,04 \\
Receivable Turn Over & $19 \mathrm{kali}$ & $64 \mathrm{kali}$ & $91 \mathrm{kali}$ \\
Firm Size & 11,76 & 11,78 & 11,82 \\
\hline
\end{tabular}

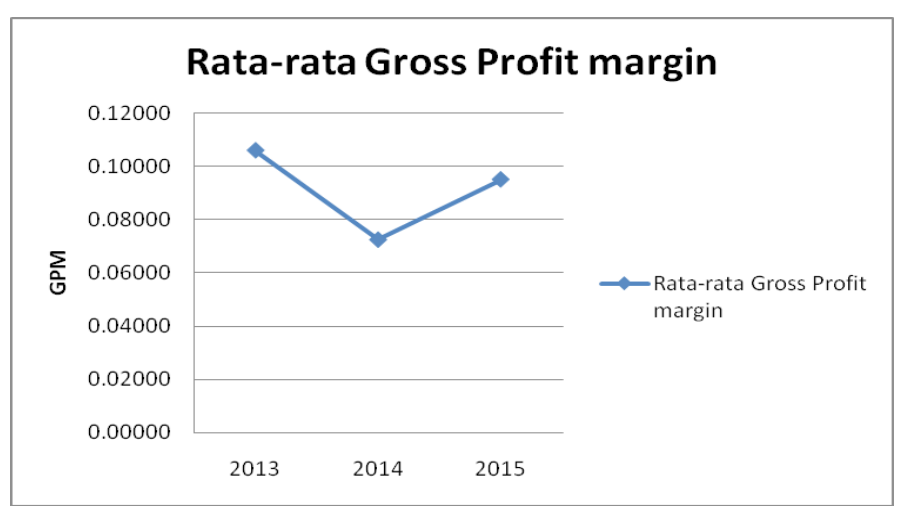

Gambar 1. Rata-rata Gross profit margin RS BLU di Jabotabek Periode 2013 - 2015 
Gambar 1 menunjukkan pergerakan Gross profit margin selama periode 2013 sampai 2015 yang mengalami fluktuatif. Pada 2014 Gross profit margin mengalami penurunan, dari $10,59 \%$ (2013) menjadi 7,25\% di tahun 2014. Pada tahun 2015 mengalami kenaikan lagi menjadi 9,51\%.

Cash ratio rata-rata untuk 10 badan layanan umum rumah sakit di wilayah Jabotabek, terjadi pergerakan atau fluktuasi periode 2013 sampai 2015, titik terendah tahun 2013 sebesar 12,03 dan titik tertinggi tahun 2014 sebesar 46,57 dan kembali turun pada tahun 2015 sebesar 19,05. Receivable turn over rata-rata periode 2013 sampai 2015 mengalami peningkatan dari tahun ke tahun. Tahun 2014 terjadi kenaikan, dari 19 kali menjadi 64 kali Pada tahun 2015 mengalami kenaikan kembali menjadi 90 kali. Rata-rata Firm Size yang diukur menggunakan log total asset selama 3 periode yaitu tahun 2013-2015 yang mengalami pergerakan. Pada tahun 2013 ke 2014 Firm Size mengalami kenaikan yaitu 11,76 menjadi 11,7. Pada tahun 2015 mengalami kenaikan kembali menjadi 11,82.

Hasil penelitian Vernando (2013) menyatakan bahwa Perputaran Piutang dan Size Perusahaan secara parsial maupun simultan tidak berpengaruh terhadap profitabilitas dengan obyek penelitian pada perusahaan otomotif yang terdaftar di BEI periode 2009-2012 dan hasil penelitian Sufianti dan Purnawati (2013) menyatakan perputaran piutang berpengaruh secara simultan terhadap profitabilitas dengan obyek penelitian pada perusahaan food and beverages yang terdaftar di BEI periode 20082010. Sedangkan hasil penelitian Wasono (2013) menyatakan Kinerja Industri Rumah Sakit BLU (pengukuran rasio keuangan) tidak berpengaruh sebelum dan sesudah ditetapkan menjadi Badan Layanan Umum.

Penelitian ini bertujuan untuk mengidentifikasi dan menganalisis pengaruh signifikan cash ratio, receivable turn over, firm size terhadap kinerja keuangan badan layanan umum rumah sakit yang berada di wilayah Jabotabek.

\section{Kajian Teori dan Pengembangan Hipotesis}

\section{Hubungan gross profit margin dengan profitabilitas}

Cash Ratio menunjukkan kemampuan perusahaan untuk membayar kewajibankewajibannya yang jatuh tempo. Rasio kas (cash ratio) merupakan alat yang digunakan untuk mengukur seberapa besar uang kas yang tersedia untuk membayar utang (Kasmir, 2010:139). Rasio ini dapat menunjukkan kemampuan perusahaan untuk membayar kewajiban jangka pendeknya. Sebuah perusahaan dalam menjalankan operasinya membutuhkan dana yang sangat besar, baik untuk produksi maupun untuk investasi. Kebutuhan dana ini tidak dapat sepenuhnya dipenuhi menggunakan modal sendiri. Oleh karena itu, perusahaan harus melakukan peminjaman dana ke pihak lain ataupu melakukan penundaan pembayaran beberapa kewajiban. Utang yang dimiliki oleh perusahaan harus dikelola sedemikian rupa sehingga tidak menambah beban bagi perusahaan yang pada akhirnya dapat menyebabkan kerugian. Rasio utang dalam sebuah laporan keuangan menunjukkan seberapa besar aset yang dibiayai dengan utang. Rasio ini menekankan pada peran penting pendanaan utang bagi perusahaan dengan menunjukkan persentase aktiva perusahaan yang didukung oleh pendanaan utang (Horne dan Wachowicz, 2009).

Dengan mengetahui seberapa besar persentase utang yang dimiliki, perusahaan dapat mencegah terjadinya gagal bayar. Perusahaan yang memiliki rasio lancar yang semakin besar, maka menunjukkan semakin besar kemampuan perusahaan untuk memenuhi kewajiban jangka pendeknya. Hal ini menunjukkan perusahaan melakukan penempatan dana yang besar pada sisi aktiva lancar. Penempatan dana yang terlalu besar pada sisi aktiva memiliki dua efek yang sangat berlainan. Di satu sisi, likuiditas perusahaan semakin baik. Namun di sisi lain, perusahaan kehilangan kesempatan untuk 
mendapatkan tambahan laba, karena dana yang seharusnya digunakan untuk investasi yang menguntungkan perusahaan, dicadangkan untuk memenuhi likuiditas. Semakin besar rasio ini, semakin besar likuiditas perusahaan. Menurut Horne dan Wachowicz (2009) likuiditas perusahaan berbanding terbalik dengan profitabilitas. Maksudnya, semakin tinggi likuiditas perusahaan maka kemampuan perusahaan untuk menghasilkan laba semakin rendah. Handayani, dkk (2016), Suminar (2015), Putrid an Musmini (2013) membuktikan bahwa perputaran kas mempengaruhi profitabilitas. Dari uraian diatas, dapat ditarik sebuah hipotesis sebagai berikut :

$\mathrm{H}_{1}$ : Cash ratio berpengaruh terhadap kinerja rumah sakit BLU

\section{Hubungan receivable turnover dengan profitabilitas}

Piutang muncul karena perusahaan melakukan penjulan secara kredit untuk meningkatkan volume usahanya. Riyanto (2001:90) menyatakan Receivable Turnover menunjukkan periode terikatnya modal kerja dalam piutang dimana semakin cepat periode berputarnya menunjukkan semakin cepat perusahaan mendapatkan keuntungan dari penjualan kredit tersebut, sehingga kinerja perusahaan yang diukur menggunakan net profit margin perusahaan juga ikut meningkat. Hal ini didukung oleh hasil penelitian dari Andarai, dkk (2016), Putra (2010), Santoso (2013) yang menyatakan bahwa tingkat Receivable Turnover berpengaruh terhadap kinerja keuangan. Berdasarkan teori yang telah diuraikan diatas dan penelitian sebelumnya yaitu Sufianti dan Purnawati (2013); Suminar (2015), Yuliani dan Salim (2013) yang menyatakan bahwa Receivable Turnover berpengaruh pada profitabilitas maka dirumuskan hipotesis sebagai berikut:

$\mathrm{H}_{2}$ : Receivable Turnover berpengaruh terhadap kinerja rumah sakit BLU

\section{Hubungan firm size dengan profitabilitas}

Devi (2011) menyebutkan bahwa menurut teori critical, semakin besar skala perusahaan maka profitabilitas juga akan meningkat, tetapi pada titik atau jumlah tertentu ukuran perusahaan akhirnya akan menurunkan laba (profit) perusahaan. Teori critical menekankan pada pengendalian oleh pemilik perusahaan terhadap sumber daya perusahaan seperti aset, teknologi, kekayaan intelektual sebagai faktorfaktor yang menentukan ukuran perusahaan.

Dengan adanya sumber daya yang besar, maka perusahaan dapat melakukan investasi baik untuk aktiva lancar maupun aktiva tetap dan juga memenuhi permintaan produk. Hal ini akan semakin memperluas pangsa pasar. Dengan adanya penjualan yang semakin meningkat, perusahaan dapat menutup biaya yang keluar pada saat proses produksi. Dengan begitu, laba perusahaan akan meningkat.

Berdasarkan teori yang telah diuraikan diatas dan penelitian sebelumnya yaitu Sartika (2012), Nugroho dan Pengestuti(2011), Hastuti (2010), Ambarwati, dkk (2015) yang menyatakan bahwa ukuran perusahan berpengaruh terhadap profitabilitas maka dirumuskan hipotesis sebagai berikut:

$\mathrm{H}_{3}$ : Ukuran perusahaan berpengaruh terhadap kinerja rumah sakit BLU

\section{Metode}

Penelitian ini merupakan penilaian kuantitatif menggunakan data sekunder diperoleh dari laporan keuangan badan layanan umum rumah sakit se-Jabotabek selama tahun 2013 sampai 2015. Pemilihan sampel dalam penelitian ini mengunakan metode purposive sampling yaitu teknik penentuan sampel dengan menggunakan pertimbangan dan kriteria tertentu, yaitu badan layanan umum rumah sakit di wilayah Jabotabek yang memperoleh gross profit margin selama tahun 2013 sampai 2015. Metode pengumpulan data penelitian adalah dengan metode dokumentasi, yaitu data 
yang diperoleh dari berbagai dokumen laporan keuangan. Setelah dokumentasi dikumpulkan, diseleksi, dan kemudian diolah. Pengujian hipotesis dilakukan dengan analisis regresi berganda (multiple regression analysis) dengan menggunakan alat bantu SPSS 22.

Pengujian hipotesis diawali dengan uji asumsi klasik, meliputi, uji normalitas, uji multikolinearitas, uji heteropskedastisitas. Uji model digunakan hasil uji F. Uji hipotesis menggunakan hasil uji t, dimana jika nilai p-value hasil uji-t masing-masing variable $<0,05$ maka hipotesis nol ditolak dan hipotesis penelitian terbukti.

\section{Hasil Penelitian dan Pembahasan}

Hasil uji normalitas menunjukan bahwa gross profit margin sebagai variabel terikat dan cash ratio, receivable turnover dan firm size sebagai variabel bebas, memiliki residual yang terdistribusi normal. Hal ini ditunjukan dengan signifikasi asymp.sig. (2-taileg) sebesar 0,173 lebih besar dari 0,05. Nilai Asymp Sig diatas 0,05 dalam tabel 0,173 berarti signifikan.

Hasil uji multikolinearitas dapat dilihat dari nilai tolerance dan variance inflation factor. Semua variabel independen, Cash Ratio, Receivable Turn Over dan Firm Size memiliki nilai tolerance lebih besar dari 0,10 dan nilai VIF lebih kecil dari 10. Berdasarkan hasil tersebut, tidak terdapat multikolinearitas.

Hasil uji autokorelasi menunjukan bahwa nilai Durbin-Watson sebesar 1,91596. Dengan significance level 0,05 , jumlah sample 30 , dan variable bebas (k) 3, table DW du 1,650 < $1,91596<2,08404$ maka diperkirakan tidak terjadi pelanggaran autokorelasi.

Hasil pengujian heteroskedastisitas ditunjukan pada grafik scatterplot terlihat bahwa titiktitik menyebar secara acak serta tersebar baik di atas maupun di bawah angka nol pada sumbu Y maka dapat disimpulkan bahwa tidak terjadi gejala heteroskedastisitas.

Tabel 2. Rangkuman Hasil Pengujian

\begin{tabular}{lrrrc}
\hline Keterangan & \multicolumn{1}{c}{ B } & Std. Error & t-hitung & Sig. \\
\hline Cash Ratio & $-0,048$ & 0,095 & $-0,509$ & 0,615 \\
RTO & 0,279 & 0,134 & 2,704 & 0,048 \\
Firm size & 0,607 & 0,130 & 4,667 & 0,000 \\
Constant & 12,787 & 7,728 & 1,655 & 0,110 \\
R-Square & 0.731 & & & \\
Adjusted R-Square & 0.700 & & & \\
F-hitung & 23,558 & & & \\
Sig. F & 0.000 & & & \\
\hline
\end{tabular}

Persamaan model regresi liniear berganda dalam penelitian ini dapat dinyatakan sebagai :

$$
\text { GPM }=12,787-0,048 \mathrm{CR}+\text { 0,279 RTO + 0,607 FIRM SIZE + e }
$$

Tabel 2 menunjukan nilai koefisien determinasi (Adjusted R-Square) model regresi dalam penelitian ini adalah 0,700. Artinya, besarnya variasi variable independen (CR, RTO, Size) yang berkontribusi pada variasi variable dependen (GPM) adalah sebesar 70\% sedangkan sisanya sebesar $30 \%$ dijelaskan oleh faktor-faktor lain yang tidak dimasukan ke dalam model regresi.

Nilai signifikan Cash Ratio 0,615 lebih besar dari 0,05 , menyatakan bahwa cash ratio tidak berpengaruh terhadap gross profit margin. Hal ini berarti Cash Ratio secara parsial tidak berpengaruh secara signifikan terhadap kinerja 
rumah sakit. Pergerakan perputaran kas yang terjadi secara parsial tidak berdampak apapun terhadap gross profit margin yang dihasilkan.

Hasil uji F menunjukkan nilai signifikansi sebesar p-value 0,000 lebih kecil dari 0,05. Berarti Rasio Kas, Perputaran Piutang dan Ukuran Perusahaan secara simultan secara bersama-sama berpengaruh signifikan terhadap variable dependen (gross profit margin).

Nilai signifikan receivable turn over 0,048 lebih kecil dari 0,05, menyatakan bahwa Perputaran Piutang berpengaruh signifikan positif secara parsial terhadap kinerja rumah sakit. Pergerakan Perputaran Piutang yang terjadi secara parsial akan berdampak pada gross profit margin yang searah. Nilai signifikan firm size 0,00 lebih kecil dari 0,05 , berarti firm size berpengaruh terhadap probabilitas $\mathrm{Hal}$ ini berarti firm size secara parsial berpengaruh secara signifikan terhadap kinerja keuangan rumah sakit (gross profit margin gross profit margin). Oleh karena itu frekuensi atas pergerakan Ukuran Perusahaan yang terjadi secara parsial berdampak terhadap gross profit margin yang dihasilkan.

\section{Hubungan antara gross profit margin dengan profitabilitas}

Hasil penelitian menunjukan bahwa cash ratio tidak berpengaruh terhadap probabilitas. Hal ini berarti Cash Ratio secara parsial tidak berpengaruh secara signifikan terhadap kinerja keuangan badan layanan umum rumah sakit. Hasil ini mengindikasikan bahwa kinerja perusahaan yang diperoleh rumah sakit badan layanan umum umumnya bukan dipengaruhi oleh rasio kas karena kinerja perusahaan pada rumah sakit badan layanan umum lebih dominan dipengaruhi oleh persediaan, leverage, pertumbuhan perusahaan dan kemungkinan variable lain yang tidak diteliti.

Kas memang seringkali menjadi tolak ukur pencapaian kinerja perusahaan, artinya jika perusahaan memiliki kas yang tinggi atau perputran kas yang semakin cepat maka dapat dikatakan bahwa kinerja perusahaan, artinya jika perusahaan memiliki kas yang tinggi atau Rasio Kas yang besar maka dapat dikatakan bahwa kinerja perusahaan juga tinggi. Akan tetapi, walaupun rasio kas besar di dalam siklus perputarannya dihasilkan dari perputaran piutang karena adanya penjualan jasa pelayanan, namun umumnya dihasilkan dari variable lainnya. Disamping itu, alasan lain bahwa target penjualan yang ditetapkan pada rumah sakit-rumah sakit badan layanan umum untuk mencapai kinerja tertentu umumnya juga menjadi salah satu faktor lain penyebab tidak terlalu diperhatikannya ketersediaan kas atau rasio kas, sehingga kinerja yang dicapai tidak tergantung pada semakin tingginya rasio kas tersebut.

Rumah sakit-rumah sakit yang berstatus Badan Layanan Umum kebanyakan menjadi rumah sakit rujukan dari rumah sakit satelit di sekitarnya. Hal ini berdampak semakin banyak jenis pelayanan kesehatan yang harus dilaksanakan oleh rumah sakit, dan semakin banyak jenis pelayanan yang dilakukan maka semakin banyak transaksi yang berkaitan dengan kas, baik untuk belanja modal dan belanja operasional juga untuk belanja rutin alat kesehatan, farmasi dan alat tulis dan kelontong. Disamping itu transaksi kas juga terjadi dari pembayaran tunai dan non tunai dari pasien. Untuk yang non tunai dengan melakukan penundaan pencatatan pada arus kas masuknya sehingga dapat berpengaruh pada kinerja rumah sakit.

Pasien yang dilayani oleh rumah sakitrumah sakit yang sudah berstatus badan layanan umum rata-rata kurang lebih $90 \%$ adalah pasien jaminan. Pasien jaminan ini menimbulkan piutang yang terkadang terdapat kendala tersendiri dalam penagihannya dan tentunya akan berdampak terhadap kinerja rumah sakitrumah sakit yang berstatus badan layanan umum.

Hasil penelitian ini berbeda dengan penelitian yang dilakukan oleh Nugroho dan Pangestuti (2011) yang menyatakan likuiditas secara parsial 
dan simultan berpengaruh terhadap profitabilitas pada perusahaan manufaktur yang terdaftar pada BEI pada tahun 2005-2009. Semakin tinggi cash ratio menunjukan kemampuan kas perusahaan untuk memenuhi (membayar) kewajiban jangka pendeknya (Brigham,1983).

\section{Hubungan antara receivable turnover dengan profitabilitas}

Hasil penelitian menunjukan receivable turnover secara parsial berpengaruh secara signifkan terhadap kinerja keuangan badan layanan umum rumah sakit. Oleh karena itu frekuensi atas pergerakan Perputaran Piutang yang terjadi secara parsial akan berdampak positif searah dengan gross profit margin.

Variabel RTO memiliki hubungan yang positif terhadap gross profit margin berarti setiap perubahan RTO akan mengakibatkan perubahan GPM yang searah bila variable lainnya konstan, dengan kata lain apabila perputaran piutang naik maka pengaruh pula pada kenaikan kinerja rumah sakit. Dengan demikian dapat disimpulkan bahwa perputaran piutang (RTO) berpengaruh signifikan terhadap kinerja rumah sakit (gross profit margin).

Hasil penelitian ini mengindikasikan bahwa kinerja yang diperoleh rumah sakitrumah sakit yang berstatus Badan Layanan Umum dipengaruhi oleh salah satu variable yaitu perputaran piutang. Piutang menjadi salah satu ukuran atas pencapaian kinerja rumah sakit, artinya jika rumah sakit-rumah sakit yang berstatus Badan Layanan Umum memiliki perputaran piutang yang semakin cepat maka dapat dikatakan bahwa kinerja rumah sakit juga tinggi. Disamping itu, semakin cepat perputaran piutang dapat mengindikasikan bahwa tingkat penjuialan jasa rumah sakit semakin tinggi dan berimplikasi juga pada berkurangnya piutang ragu-ragu yang dicadangkan sehingga kinerja yang dicapai rumah sakit akan semakin tinggi pula.

Kementerian Kesehatan Republik Indonesia menghendaki terjadinya peningkatan pelayanan kesehatan pada rumah sakit- rumah sakit yang sudah berstatus Badan Layanan Umum. Peningkatan pelayanan ini dapat dilihat dari seberapa cepat rumah sakit dapat menangani pasien tanpa adanya hambatan yang diakibatkan kurangnya sarana prasarana yang diakibatkan oleh sulitnya rumah sakit mendapatkan uang kas dikarenakan sulitnya menagih piutang yang ada. Sehingga perputaran piutang yang cepat menjadi salah satu indikasi baiknya kinerja rumah sakit yang bersangkutan. Oleh karena itu, penelitian ini mengindikasikan bahwa pengaruh RTO terhadap GPM akan bergerak searah jika perputaran piutang (RTO) bergerak naik maka akan berimplikasi pada kenaikan kinerja rumah sakit.

Hasil penelitian ini konsisten dan sesuai dengan penelitian Vernando (2013) yang menyatakan bahwa perputaran piutang secara parsial maupun simultan berpengaruh terhadap profitabilitas pada perusahaan otomotif yang terdaftar di BEI periode 2009-2012.

\section{Hubungan antara firm size dengan profitabilitas}

Hasil penelitian menunjukkan firm size berpengaruh terhadap probabilitas $\mathrm{Hal}$ ini berarti firm size secara parsial berpengaruh secara signifikan terhadap kinerja keuangan rumah sakit (gross profit margin), Variabel firm size memiliki hubungan yang positif terhadap gross profit margin berarti perubahan firm size akan mengakibatkan perubahan gross profit margin dengan perubahan yang searah bila variable lainnya dianggap konstan, dengan kata lain firm size naik maka akan menaikan kinerja rumah sakit. Dengan demikian dapat disimpulkan bahwa ukuran perusahaan / firm size berpengaruh signifikan terhadap kinerja rumah sakit (gross profit margin). Firm size adalah perhitungan angka linier dari total asset yang menggambarkan besarnya firm size rumah sakit sebagai modal aktivitas operasionalnya.

Hasil penelitian ini mengindikasikan bahwa asset yang dimiliki rumah sakit dapat 
digunakan untuk aktivitas operasional sehingga kinerja keuangan rumah sakit dapat menjadi baik dikarenakan memiliki modal yang baik pula. Besarnya asset rumah sakit dapat menjadi gambaran bahwa rumah sakit tersebut dapat dan mampu melakukan pelayanan kesehatan yang baik dikarenakan optimalisasi asset berjalan dengan baik.

Hasil penelitian ini konsisten dan sesuai dengan penelitian Vernando (2013) yang menyatakan bahwa Size Perusahaan secara parsial maupun simultan berpengaruh terhadap profitabilitas pada perusahaan otomotif yang terdaftar di BEI periode 2009-2012.

\section{Simpulan, keterbatasan dan Implikasi Hasil Penelitian}

Beberapa temuan diperoleh dari penelitian ini dan dapat disimpulkan bahwa variable cash ratio tidak berpengaruh terhadap gross profit margin. Sedangkan Variable receivable turn over dan Variable firm size secara parsial berpengaruh signifikan positif terhadap gross profit margin. Pengaruh receivable turnover yang tinggi, berdampak pada kinerja keuangan semakin baik, begitu pula semakin tinggi aset Badan Layanan Umum rumah sakit semakin tinggi kinerja keuangan rumah sakit tersebut. Pada sisi lain, variabel cash ratio, receivable turnover dan firm size secara simultan berpengaruh terhadap kinerja keuangan badan layanan umum rumah sakit.

\section{Daftar Referensi}

Akbar, N., \& Kinanti, L. (2013). Analisis Pengaruh Rasio Aknvitas, Leverage Keuangan, Ukuran, Dan Umur Perusahaan Terhadap Profitabilitas Perusahaan Wholesale And Retail Trade Yang Terdaftar Di Bursa Efek Indonesia. Jurnal Ekonomi, 17(03).

Ambarwati, N. S., Yuniarta, G. A., \& Sinarwati, N. K. (2015). Pengaruh Modal Kerja, Likuiditas, Aktivitas Dan Ukuran Perusahaan Terhadap Profitabilitas Pada
Perusahaan Manufaktur Yang Terdaftar Di Bursa Efek Indonesia. JIMAT (Jurnal Ilmiah Mahasiswa Akuntansi) Undiksha, 3(1).

Andari, Y., Arifati, R., \& Andini, R. (2016). Pengaruh Perputaran Barang Jadi, Arus Kas, Piutang, dan Aktiva Tetap Terhadap Profitabilitas Pada Perusahaan Perdagangan Eceran yang Terdaftar di BEI Periode 20092014. Journal Of Accounting, 2(2).

Devi, M. S. (2011). Faktor-Faktor Yang Mempengaruhi Profitabilitas Pada Perusahaan Kimia \& Farmasi Yang Terdaftar Di Bursa Efek Indonesia Tahun 2008-2011. Jurnal. Universitas Maritim Raja. Tanjung Pinang, 3(1).

Hastuti, N., \& Haryanto, M. (2010). Analisis Pengaruh Periode Perputaran Persediaan, Periode Perputaran Hutang Dagang, Rasio Lancar, Leverage, Pertumbuhan Penjualan dan Ukuran Perusahaan Terhadap Profitabilitas Perusahaan (Studi pada: Perusahaan Manufaktur yang Terdaftar di BEI pada tahun 2006-2008) (Doctoral dissertation, Universitas Diponegoro).

Horne, J. V, Warchowich, (2000), Financial management and Policy, Prentice Hall : New Jersey

Nugroho, E., \& Pangestuti, I. R. D. (2011). Analisis Pengaruh Likuiditas, Pertumbuhan Penjualan, Perputaran Modal Kerja, Ukuran Perusahaan dan Leverage terhadap Profitabilitas Perusahaan (Studi pada Perusahaan Manufaktur yang Terdaftar pada BEI pada Tahun 2005-2009) (Doctoral dissertation, Universitas Diponegoro).

Putra, L. J. (2012). Pengaruh Perputaran Modal Kerja Terhadap Profitabilitas (Studi Kasus: PT. Indofood Sukses Makmur Tbk.). Jurnal Ekonomi Gunadarma, 9(1), 1-10.

Putri, L. R., \& Musmini, L. S. (2013). Pengaruh Perputaran Kas terhadap Profitabilitas pada PT. Tirta Mumbul Jaya Abadi Singaraja Periode 2008-20012. Jurnal Akuntansi Profesi, 3(2). 
Santoso, C. E. (2013). Perputaran modal kerja dan perputaran piutang pengaruhnya terhadap profitabilitas pada PT. Pegadaian (PERSERO). Jurnal EMBA: Jurnal Riset Ekonomi, Manajemen, Bisnis dan Akuntansi, 1(4).

Sartika, D. (2012). Analisis pengaruh ukuran perusahaan, kecukupan modal, kualitas aktiva produktif dan likuiditas terhadap return on assets (ROA). Makassar: Universitas Hasanuddin.

Sufiana, N., \& Purnawati, N. K. (2013). Pengaruh Perputaran Kas, Perputaran Piutang dan Perputaran Persediaan Terhadap Profitabilitas. E-Jurnal Manajemen Universitas Udayana, 2(4), 451-467.

Suminar, M. T. (2015). Pengaruh Perputaran Persediaan, Perputaran Piutang Dan Perputaran Kas Terhadap Profitabilitas Pada Perusahaan Sektor Industri Barang Konsumsi Yang Terdaftar Di BEI Periode 2008-2013. Journal Of Accounting, l(1).
Sunarto, S., \& Budi, A. P. (2009). Pengaruh Leverage, Ukuran dan Pertumbuhan Perusahaan Terhadap Profitabilitas. Jurnal Ilmiah Telaah Manajemen, 6(1).

Vernando, R. Y. (2013). Pengaruh Perputaran Piutang, Perputaran Persediaan dan Size Perusahaan terhadap Profitabilitas (ROA) pada Perusahaan Otomotif yang Terdaftar di Bursa Efek Indonesia (BEI) Periode 2009-2012. Jurnal Ekonomi.(online).

Wasono, Sarifudin, Joko. (2013).,. Analisis Perbedaan Kinerja Keuangan Industri Rumah Sakit BLU Pada Sebelum dan SesudahDitetapkan sebagai Badan Layanan Umum Di Lingkungan Kementerian Kesehatan Republik Indonesia. Jakarta: Magister Akuntansi, Universitas Pancasila. Yuliani, R., \& Salim, U. (2013). Pengaruh Perputaran Piutang Terhadap Profitabilitas Pada Perusahaan Pt. Unilever Indonesia Tbk. Tahun 2005-2012. Jurnal Ekonomi dan Bisnis. 